\title{
Effects of Leadership, Organizational Culture, and Competence on Procurement of Government Goods and Services at the Directorate of Prevention and Control of Direct Communicable Diseases of the Ministry of Health of the Republic of Indonesia
}

\author{
Surya Pujoyono ${ }^{1}$, Bahrullah Akbar ${ }^{2}$, Aries Djaenuri ${ }^{3}$, Muh. Ilham ${ }^{4}$ \\ 1,2,3,4 Institut Pemerintahan Dalam Negeri (IPDN), Indonesia \\ Email: surya.pujoyono@ipdn.ac.id
}

\begin{abstract}
The research objective is to determine the effect of leadership on government procurement of goods and services, organizational culture of government procurement of goods and services, competence on government procurement of goods and services, leadership influence through organizational culture on government procurement of goods and services, leadership influence through competence on procurement of goods and government services, and formulate new concepts from the results of the discussion of the effects of leadership, organizational culture, and competence on the procurement of government goods and services. The research sample of 104 respondents was taken fully / fully. Data collection in this research uses a literature study, a research questionnaire, and observation. Data analysis using SEM Analysis. The results found that leadership influences Organizational Culture, Leadership influences Competence, Organizational Culture influences Government Procurement of Goods and Services, Competence influences Government Procurement of Goods and Services, and Leadership influences Government Procurement of Goods and Services.
\end{abstract}

Kata Kunci: Kepemimpinan, Budaya Organisasi, Kompetensi, Pengadaan Barang dan Jasa Pemerintah.

\section{A. INTRODUCTION}

The procurement of government goods and services within the Ministry of Health of the Republic of Indonesia must comply with regulations related to procurement, both at the level of the Presidential regulation and the regulations of the Head of the Government Goods / Services Procurement Policy Agency (LKPP). To support the procurement of government goods and services in accordance with the characteristics of the Ministry of Health, the Minister of Health issued several Minister of Health Regulations (Permenkes) namely Permenkes Number 462 of 2010 concerning Procurement of Electronic Goods / Services in the Ministry of Health Environment, Permenkes Number 463 of 2010 concerning Organization and Work Procedures Electronic Procurement Service Unit (LPSE) in the Ministry of Health, and Permenkes Number 1893 of 2011 concerning Goods / Services Procurement Service Unit (ULP) in the Ministry of Health. The considerations underlying this Permenkes include that to further improve efficiency, effectiveness, transparency, fair competition and accountability in the implementation 
of goods/services procurement within the Ministry of Health, electronic goods/services procurement should be carried out.

Government procurement of goods/services electronically is carried out by organizers consisting of elements of LPSE, PPK, Procurement Committee and Goods/Services Providers. LPSE, PPK, Procurement Committee and legally available Goods/Services Providers: confidentiality and misuse of access codes (User ID and Password) in the operation of electronic goods / services; confidentiality and misuse of data and electronic information not intended for public use; fulfill the provisions in force in the procurement of goods/services. LPSE, PPK, Procurement Committee and Provider of Goods/Services are prohibited: disrupt, and/or damage the system of procurement of goods/services electronically; steal information, manipulate data, and/or cheat in the procurement of goods/services electronically that can affect procurement goals. In addition to fulfilling the provisions as referred to, LPSE, PPK, the Procurement Committee and the Goods/Services Provider must comply with the ethics of the procurement of goods/services as stipulated in the legislation.

Regarding the procurement ethics referred to, Presidential Regulation Number 54 of 2010 concerning Procurement of Government Goods / Services as amended several times, most recently Presidential Regulation Number 172 of 2014 concerning the Third Amendment to Presidential Regulation Number 54 of 2010 concerning Procurement of Government Goods / Services containing Principles - Procurement Principles and Procurement Ethics. The principles of procurement of goods and services referred to include efficient; effective; transparent; open; compete; fair and or nondiscriminatory; and accountable. Whereas procurement ethics include:

1. The implementation of tasks in an orderly manner, accompanied by a sense of responsibility to achieve the goals, smoothness, and accuracy in achieving the objectives of the procurement of goods/services;

2. Work carried out professionally and independently, as well as maintaining the confidentiality of goods/services procurement documents which by their nature must be felt to prevent irregularities in procuring goods/services;

3. Does not affect each other directly or indirectly resulting in unfair competition;

4. Accept and be responsible for all decisions made in accordance with the written agreement of the parties;

5. Avoid and prevent conflicting interests of the parties involved either directly or indirectly in the process of procurement of goods/services;

6. Avoid and prevent waste and leakage of state finances in the procurement of goods/services; Avoid and prevent the abuse of authority and/or collusion with the aim of a person, group or other party benefits directly or indirectly harming the State; and 
7. Do not accept, not offer or do not promise to give or receive gifts, rewards, commissions, rebates, and in whatever form from or to anyone who is known or reasonably suspected in connection with the procurement of goods/services.

Procurement of goods/services in the environment Direktorat P2PML seems to be a phenomenon of bureaucratic performance that cannot be separated from the influence of various variables. The phenomenon in question is a symptom, event, event or certain circumstances that take place in the process of implementing policies and activities in the procurement of goods and services in the health sector. The impact of the phenomenon is certainly not limited to the internal environment of the directorate alone. The external environment or society can also be affected by this phenomenon. The intended impacts include the performance of preventing and controlling direct infectious diseases such as tuberculosis and HIV AIDS is not optimal.

With regard to the phenomena drawn from the problems and their causes, it is assumed that Leadership, Organizational Culture, and Competence are the three variables that have a significant effect on the Procurement of Government Goods and Services in the Directorate of Prevention and Control of Direct Communicable Diseases. This assumption is based on the following major and minor premises:

Leadership, which is a process of social interaction that takes place between elements of leadership and staff in implementing policies and or activities of the Directorate, dynamically correlates with the views, attitudes, and behavior of the apparatus in carrying out their work. The cause of the problem in the form of KPA officials' weaknesses in controlling the procurement process of goods and services that have been revealed by the BPK can be indicated as a Leadership variable. Therefore, conditionally and functionally, Leadership certainly influences the Procurement of Government Goods and Services in the Directorate of Prevention and Control of Direct Communicable Diseases.

Leadership as the ability to influence a group toward the achievement of goals. The sources of this influence may be formal, such as that provided by the possession of managerial rank in an organization. Since management positions come with some degree of formally designated authority, a person may assume a leadership role simply because of the position he or her holds in the organization. But not all leaders are managers; not for that matter, are all managers leaders. Just because an organization provides its managers with certain formal rights is no assurance that they will be able to lead effectively. We find the nonsanctioned leadership that is, the ability to influence that arises outside the formal structure of the organization is often as important than formal influence (Robbins (1998).

Organizational Culture, namely the value system that is internalized and actualized into the apparatus's beliefs, norms and work ethics, dynamically correlates with the apparatus's views, attitudes and behavior in carrying out its work. The cause of the problem in the form of non-compliance of various parties in the procurement of goods 
and services that have been revealed by the BPK can be indicated as a variable Organizational Culture. Therefore, conditionally and functionally, Organizational Culture certainly influences the Procurement of Government Goods and Services in the Directorate of Prevention and Control of Direct Communicable Diseases.

Organizational culture is the set of shared values, beliefs, and norms that influence the way employees think, feel, and behave toward each other and towards people outside the organization. In Schein's view, culture is "a pattern of shared basic assumptions a group learns as it solves its problems of external adaptation and internal integration, that is considered valid, is taught to new members as the correct way you perceive, think and feel in relation to those problems Just as an organization's structure can increase employee cooperation and motivation, so the values and assumptions in an organization's culture can also promote work attitudes and behaviors that increase organizational effectiveness. to their environment, what they do with information, and how they make decisions (George et al., 2005).

Competence, which is the internal factor of the apparatus which includes physical capacity, intellectual capacity, mental attitude quality and social capability which is actualized into the work environment, dynamically correlates with the views, attitudes, and behavior of the apparatus in carrying out their work. The cause of the problem in the form of unprofessional and inaccurate behavior in carrying out the tasks of procurement of goods and services that have been revealed by the BPK can be indicated as a Competency variable. Therefore, conditionally, Competence certainly affects the Procurement of Government Goods and Services in the Directorate of Prevention and Control of Direct Communicable Diseases.

Competency has two relevant meanings, the first, addresses the ability of an individual to perform effectively in a job-relevant area. The second, is a definition of what is required of an individual, for effective performance. These two are closely related but distinct. The second meaning, involves defining what is important to be successful in a job, while the first deals with the degree to which an individual does, what is important for a job. Defining job competencies is useful in assisting individuals to develop their competencies for that job. This area is related to success in a jobor role. Building on this definition, a competency model is a grouping of individual competencies, which describes all, or most of the requirements for job functions, or organizational success (Shermon, 2004).

Leadership, organizational culture, and competence which are assumed to be variables that have a significant effect on the Procurement of Government Goods and Services, are strengthened through research by Siregar (2006), Kiage (2013), Keno (2017), Kurnia (2016), Ash'ary (2017) ), Harwiki (2015) and Tsai et al. (2015). The results of research on the dynamics of the causality relationship show that there are mediating variables that connect antecedent variables with consequence variables. However, there has not been any research on the dynamics of causality relationships that make Government 
Procurement of Goods and Services a consequence variable. Based on the problem of Government Goods and Services Procurement in Direktorat P2PML, the author assumes there is an indirect relationship between the variables of Leadership with Government Procurement of Goods and Services, which is through the variable Organizational Culture and Competence.

The research objective is to determine the effect of leadership on government procurement of goods and services, organizational culture of government procurement of goods and services, competence on government procurement of goods and services, leadership influence through organizational culture on government procurement of goods and services, leadership influence through competence on procurement of goods and government services, and formulate new concepts from the results of the discussion of the effects of leadership, organizational culture, and competence on the procurement of government goods and services.

\section{B. METHOD}

This research uses a quantitative approach (Creswell, 1994; Arikunto, 1998). The number of samples in this study was taken in full from all elements of the leadership and employees of the Directorate of Prevention and Control of Direct Infectious Diseases (Direktorat P2PML) Ministry of Health of the Republic of Indonesia, amounting to 104 (Sugiyono, 2009). Data collection techniques were carried out using observation and questionnaire distribution techniques. From the data obtained through a research questionnaire, data processing and analysis will be carried out in accordance with the stated research objectives. In this study, the analytical method used is quantitative analysis with Structural Equation Modeling (SEM) (Ghozali, 2008).

\section{RESULT AND DISCUSSION}

\section{Analysis of the Effect of Leadership on Procurement of Goods and Services}

Based on the results of statistical tests, it can be seen that the t-value and path coefficient on the influence of Leadership on Procurement of Government Goods and Services at the P2PML Directorate of the Ministry of Health in this study were 0.2065 and 0.034 , respectively. The T-count value of 0.2065 indicates that leadership has not been proven empirically to have a significant effect on Government Goods and Services Procurement at the P2PML Directorate of the Ministry of Health. While the path coefficient value of -0.034 indicates that the influence is in the opposite direction (negative) and is classified as very weak. These results also indicate that Leadership does not have a causal relationship (cause and effect) directly with the quality of Government Goods and Services Procurement at the P2PML Directorate of the Ministry of Health.

Based on the results of the Confirmatory Factor Analysis (CFA) test, Direction Setter is empirically proven to be the dimension of analysis that has the highest contribution to the latent variable of Leadership. However, by looking at the results of data 
processing which shows that the latent variable of Leadership has not been proven to have a significant effect on the Procurement of Government Goods and Services at the P2PML Directorate of the Ministry of Health, then to improve the quality of Government Goods and Services Procurement at the P2PML Directorate of the Ministry of Health cannot be done through improving the quality dimensions Direction Setter.

\section{Analysis of the Effect of Organizational Culture on Procurement of Goods and Services}

Based on the results of statistical tests, it can be seen that the t-value and path coefficient on the Influence of Organizational Culture on the Procurement of Government Goods and Services at the P2PML Directorate of the Ministry of Health in this study were 2.4844 and 0.403 , respectively. The t-count value of 2.4844 indicates that Organizational Culture has been proven empirically to have a significant effect on the Procurement of Government Goods and Services at the P2PML Directorate of the Ministry of Health. While the path coefficient value of 0.403 indicates that the influence is unidirectional (positive) and relatively strong. The results also indicate that Organizational Culture has a strong causal relationship with the quality of Government Goods and Services Procurement in the P2PML Directorate of the Ministry of Health. This indicates that if the quality of Organizational Culture is improved, it will necessarily improve the quality of Government Goods and Services Procurement at the P2PML Directorate of the Ministry of Health.

Therefore, the quality of Government Goods and Services Procurement at the P2PML Directorate of the Ministry of Health can be improved or improved by improving, enhancing, and optimizing 4 (four) dimensions consisting of 12 (twelve) manifest variables. The four dimensions that can be optimized are Personal and Professional Characteristics, Organizational Ethics, The Nature of the Employment Relationship, and Organizational Structure. Whereas the twelve (12) manifest variables that can be optimized are Personal Characteristics, Personal Professionalism, Personal Professionalism, Individual Ethics, Group Ethics, Organizational Ethics, Relationships between Leaders, Leaders to Staff Relationships, Relationships between Staff, Distribution of Authorities, Distribution of Tasks and responsibility, and Coordination.

Based on the results of the Confirmatory Factor Analysis (CFA) test, The Nature of the Employment Relationship is empirically proven to be the analytical dimension that has the highest contribution to the latent variables of Organizational Culture. Therefore, to improve the quality of Government Goods and Services Procurement at the P2PML Directorate of the Ministry of Health can be done by making quality improvement of the Nature of the Employment Relationship dimension a top priority.

The Nature of the Employment Relationship dimension consists of 3 (three) manifest variables, namely Relationship between leaders, Relationship between leaders and staff, and Relationships between staff. Furthermore, it is also known, that of the 3 
(three) manifest variables, the relationship between staff was empirically proven to have the highest contribution. So, based on these results, it can be said that to improve the quality of Government Goods and Services Procurement, the quality of relations between staff is a top priority that must be improved compared to the 2 (two) other manifest variables.

\section{Analysis of the Effect of Competence on Procurement of Goods and Services}

Based on the results of statistical tests, it can be seen that the t-value and path coefficient on the effect of Competence on the Procurement of Government Goods and Services at the P2PML Directorate of the Ministry of Health in this study are 4.664 and 0.528 , respectively. The $t$-value of 4.664 indicates that competence has been proven empirically to have a significant effect on the Procurement of Government Goods and Services at the P2PML Directorate of the Ministry of Health. While the path coefficient value of 0.528 indicates that the influence is unidirectional (positive) and relatively strong. The results also indicate that competence has a strong causal relationship with the quality of Government Goods and Services Procurement at the P2PML Directorate of the Ministry of Health. This indicates that if the quality of Competency is improved, it will necessarily improve the quality of Government Goods and Services Procurement at the P2PML Directorate of the Ministry of Health.

Therefore, the quality of Government Goods and Services Procurement at the P2PML Directorate of the Ministry of Health can be improved or improved by improving, enhancing, and optimizing 5 (five) dimensions consisting of 15 (fifteen) manifest variables. The five dimensions that can be optimized are Motives, Traits, SelfConcepts, Knowledge, and Skills. Whereas fifteen (15) manifest variables that can be optimized are motivation to serve, motivation to serve, achievement motivation, character, appearance, attitude, behavior, knowledge about work administration, knowledge about activity management, knowledge about technical work, skills managerial, technical skills, and social skills.

Based on the results of the Confirmatory Factor Analysis (CFA) test, Self Concept is empirically proven to be the analytical dimension that has the highest contribution to the competency latent variable. Therefore, to improve the quality of Government Goods and Services Procurement at the P2PML Directorate of the Ministry of Health can be done by making the quality improvement of the Self Concept dimension a top priority.

Dimensions of Self Concept consists of 3 (three) manifest variables, namely Selfdisplay, Attitude, and Behavior. Furthermore, it is also known, that of the 3 (three) manifest variables, Behavior empirically has the highest contribution. So, based on the results of the study, it can be said that to improve the quality of Government Goods and Services Procurement, the quality of Behavior is a top priority that must be improved compared to the 2 (two) other manifest variables. 


\section{Analysis of the Effect of Leadership through Organizational Culture on Pro- curement of Goods and Services}

Based on the results of statistical tests, it can be seen that the t-value and path coefficient on the influence of Leadership on Organizational Culture at the P2PML Directorate of the Ministry of Health in this study were 2.48 and 0.79 , respectively. The $\mathrm{t}$ count value of 2.48 indicates that Leadership has been proven empirically to have a significant effect on Organizational Culture at the P2PML Directorate of the Ministry of Health. While the path coefficient value of 0.79 indicates that the influence is unidirectional (positive) and relatively strong. The results also indicate that Leadership has a strong causal relationship with the quality of Organizational Culture at the P2PML Directorate of the Ministry of Health. This indicates that if the quality of leadership is improved, it will automatically improve the quality of Organizational Culture at the P2PML Directorate of the Ministry of Health.

In addition, based on the analysis described in Subsection Chapter 4.4.2, it is known that Organizational Culture is proven to have an empirically positive and significant effect on the quality of Government Goods and Services Procurement in the P2PML Directorate of the Ministry of Health. If the quality of Organizational Culture is improved, it will immediately improve the quality of Government Goods and Services Procurement at the P2PML Directorate of the Ministry of Health.

Based on these results, then if the quality of Leadership is improved, it will necessarily improve the quality of Organizational Culture. Because the quality of Culture Organizations has increased, it will also immediately improve the quality of Government Goods and Services Procurement at the P2PML Directorate of the Ministry of Health. In other words, the quality of Government Goods and Services Procurement is influenced by leadership indirectly through Organizational Culture.

Therefore, the quality of Government Goods and Services Procurement at the P2PML Directorate of the Ministry of Health can be improved, improved and optimized by improving, enhancing, and optimizing the quality of Organizational Culture by improving, enhancing, and optimizing 4 (four) dimensions consisting of 12 (twelve) Leadership manifest variables. The four dimensions that can be optimized are Spokesperson, Direction Setter, Coach, and Change Agent. Whereas the twelve (12) manifest variables that can be optimized are the role of the leader as a spokesperson for decision making, the role of the leader as a spokesperson for policy, the role of the leader as an institutional spokesperson, the role of the leader as regulator, the role of the leader as the director, the role of the leader as the controller, The role of leaders as motivators, the role of leaders as facilitators, the role of leaders as instructors, the role of leaders as innovators of change, the role of leaders as collaborators of change, and the role of leaders as pioneers of change. 
That is Leadership which is influenced by 4 (four) dimensions and 12 (twelve) manifest variables which are in the P2PML Directorate of the Ministry of Health must be oriented towards improving the quality of Organizational Culture. These efforts can be done by directing the quality of the existing leadership to improve, enhance, and optimize the 4 (four) dimensions of Organizational Culture consisting of 12 (twelve) manifest variables. The four dimensions that can be optimized are Personal and Professional Characteristics, Organizational Ethics, The Nature of the Employment Relationship, and Organizational Structure. Whereas the twelve (12) manifest variables that can be optimized are Personal Characteristics, Personal Professionalism, Personal Professionalism, Individual Ethics, Group Ethics, Organizational Ethics, Relationships between Leaders, Leaders to Staff Relationships, Relationships between Staff, Distribution of Authorities, Distribution of Tasks and responsibility, and Coordination.

Based on the results of the Confirmatory Factor Analysis (CFA) test, Direction Setter is empirically proven to be the dimension of analysis that has the highest contribution to the latent variable of Leadership. Therefore, to improve the quality of Government Goods and Services Procurement at the P2PML Directorate of the Ministry of Health can be done by improving the quality of Organizational Culture by making the quality improvement of the Direction Setter dimension on the latent variable Leadership a top priority.

The Direction Setter dimension consists of 3 (three) manifest variables, namely the Role of the Leader as the regulator, the role of the leader as the director, and the role of the leader as the controller. Furthermore, it is also known, that of the 3 (three) manifest variables, the role of the leader as the director is empirically proven to have the highest contribution. So, based on these results, it can be said that to improve the quality of Procurement of Goods and Services the Government can be done by improving the quality of Organizational Culture by improving the quality of Leadership and making the role of the leader as the director the main priority that must be improved compared to the 2 (two) other manifest variables. Whereas based on the results of the CFA analysis of the latent variables of Organizational Culture, it is known that The Nature of The Employment Relationship and Relationships among staff are respectively the dimensions and manifest variables that have the highest contribution. Therefore, in order for the quality of Government Goods and Services Procurement to improve, the leadership's role as the director must be oriented and directed to ensure the quality of relations between staff at the P2PML Directorate of the Ministry of Health to be better (conducive). 


\section{Analysis of the Effect of Leadership Through Competence Against Procure- ment of Goods and Services}

Based on the results of statistical tests, it can be seen that the t-value and path coefficient on the influence of Leadership on Competence at the P2PML Directorate of the Ministry of Health in this study are 4.71 and 0.55 , respectively. The t-value of 4.71 indicates that leadership has been empirically proven to have a significant effect on competence at the P2PML Directorate of the Ministry of Health. While the path coefficient value of 0.55 indicates that the influence is unidirectional (positive) and relatively strong. The results also indicate that Leadership has a strong causal relationship with the quality of Competence at the P2PML Directorate of the Ministry of Health. This indicates that if the quality of leadership is improved, it will necessarily improve the quality of competence at the P2PML Directorate of the Ministry of Health.

In addition, based on the analysis described in Subsection Chapter 4.4.3, it is known that Competency has been proven empirically to have a positive and significant effect on the quality of Government Goods and Services Procurement in the P2PML Directorate of the Ministry of Health. If the quality of Competency is improved, it will immediately improve the quality of Government Goods and Services Procurement at the P2PML Directorate of the Ministry of Health.

Based on these results, then if the quality of leadership is improved, it will necessarily improve the quality of competence. Because the quality of competence increases, it will also immediately improve the quality of Government Procurement of Goods and Services at the Ministry of Health's P2PML Directorate. In other words, the quality of Government Goods and Services Procurement is influenced by leadership indirectly through Competence.

Therefore, the quality of Government Goods and Services Procurement at the P2PML Directorate of the Ministry of Health can be improved, improved, and optimized by improving, enhancing, and optimizing the quality of Competence by improving, enhancing, and optimizing 4 (four) dimensions consisting of 12 ( twelve) Leadership manifest variables. The four dimensions that can be optimized are Spokesperson, Direction Setter, Coach, and Change Agent. Whereas the twelve (12) manifest variables that can be optimized are the role of the leader as a spokesperson for decision making, the role of the leader as a spokesperson for policy, the role of the leader as an institutional spokesperson, the role of the leader as regulator, the role of the leader as the director, the role of the leader as the controller, The role of leaders as motivators, the role of leaders as facilitators, the role of leaders as instructors, the role of leaders as innovators of change, the role of leaders as collaborators of change, and the role of leaders as pioneers of change.

That is leadership that is influenced by 4 (four) dimensions and 12 (twelve) manifest variables that exist in the P2PML Directorate of the Ministry of Health must be oriented to improving the quality of competence. These efforts can be done by directing 
the quality of the existing Leadership to improve, improve, and optimize 5 (five) dimensions consisting of 15 (fifteen) manifest variables. The five dimensions that can be optimized are Motives, Traits, Self-Concepts, Knowledge, and Skills. Whereas fifteen (15) manifest variables that can be optimized are motivation to serve, motivation to serve, achievement motivation, character, appearance, attitude, behavior, knowledge about work administration, knowledge about management of activities, knowledge of technical work, skills managerial, technical skills, and social skills.

Based on the results of the Confirmatory Factor Analysis (CFA) test, Direction Setter is empirically proven to be the dimension of analysis that has the highest contribution to the latent variable of Leadership. Therefore, to improve the quality of Government Goods and Services Procurement at the P2PML Directorate of the Ministry of Health can be done by improving the quality of Competency by making quality improvement of the Direction Setter dimension on the latent variable Leadership a top priority.

The Direction Setter dimension consists of 3 (three) manifest variables, namely the Role of the Leader as the regulator, the role of the leader as the director, and the role of the leader as the controller. Furthermore, it is also known, that of the 3 (three) manifest variables, the role of the leader as the director is empirically proven to have the highest contribution. So, based on these results, it can be said that to improve the quality of Government Goods and Services Procurement can be done by increasing the quality of Competency by improving the quality of Leadership and making the role of the leader as a director the main priority that must be improved compared to the 2 (two) other manifest variables. While based on the results of the CFA analysis of latent Competency variables, it is known that Self Concept and Attitude are the dimensions and manifest variables that have the highest contribution. Therefore, in order for the quality of Government Goods and Services Procurement to increase, the leadership's role as the director must be oriented and directed to ensure the quality of the attitudes of each employee at the P2PML Directorate of the Ministry of Health to be better (good character).

\section{CONCLUSION}

The results found that leadership influences organizational culture, leadership influences competence, organizational culture influences government procurement of goods and services, competence influences government procurement of goods and services, and leadership influences government procurement of goods and services. The new concept obtained from the analysis of the influence of Organizational Culture on the Procurement of Government Goods and Services at Direktorat P2PML Ministry of Health is a new concept about The Nature of The Employment Relationship. The new concept obtained from the analysis of the effect of Competence on the Procurement of Government Goods and Services at Direktorat P2PML Ministry of Health is a new concept about Self Concept. The new concept obtained from the analysis of the influence of 
leadership on organizational culture in Direktorat P2PML Ministry of Health is a new concept about Direction Setter. The new concept obtained from the analysis of the influence of Leadership on competence in Direktorat P2PML Ministry of Health is a new concept about Direction Setter.

\section{REFERENCES}

1. Arikunto, S. (1998). Prosedur Penelitian, Suatu Pendekatan Praktek. Jakarta: Rineka Cipta.

2. Creswel, J. W. (1994). Research Design Qualitative E Quantitative Approaches. New Delhi: Sage Publication.

3. George, J. M., Jones, G. R., \& Sharbrough, W. C. (2005). Understanding and Managing Organizational Behavior. Upper Saddle River, NJ: Pearson Prentice Hall.

4. Ghozali. I. (2008). Structural Equation Modeling Metode Alternatif dengan Partial Least Square (PLS). Semarang: Badan Penerbit Universitas Diponegoro.

5. Harwiki, W. (2015). The Impact of Servant Leadership on Organization Culture, Organizational Commitment, Organizational Citizenship Behaviour (OCB) and Employee Performance in Women Cooperatives. Procedia-Social and Behavioral Sciences, 219, 283-290.

6. Keno, A. (2017). Determinants of Procurement Performance in Wolaita Sodo University: Customers' Perception. European Journal of Business and Management, $9(4)$.

7. Kiage, J. O. (2014). Factors Affecting Procurement Performance: A Case of Ministry of Energy. International Journal of Business and Commerce, 3(1), 54-70.

8. Law of the Republic of Indonesia Number 36 of 2009 concerning Health.

9. Presidential Regulation of the Republic of Indonesia Number 35 the Year 2015 concerning the Ministry of Health.

10. Regulation of the Minister of Health of the Republic of Indonesia Number 64 of 2015 concerning the Organization and Work Procedures of the Ministry of Health.

11. Regulation of the Minister of Health of the Republic of Indonesia Number 462 of 2010 concerning Procurement of Electronic Goods / Services in the Ministry of Health Environment.

12. Robbins, S. P. (1998). Organizational Behavior Concepts Controversies Applications. New Jersey: Prentice-Hall International, Inc.

13. Shermon, G. (2004). Competency Based HRM. India: McGraw-Hill Publishing Company Limited.

14. Sugiyono. (2005). Statistik Untuk Penelitian. Bandung: CV. Alfabeta.

15. Tsai, Y., Wang, H., \& Yuan, C. (2015). Transformational Leadership and Job Performance: The Case of SMEs in Taiwan. International Journal of Arts and Commerce, 4(8), 57-71. 